\title{
Productions and Functional Properties of Palm Sugars
}

\author{
Khongsak SRIKAEO ${ }^{1, *}$, Janya SANGKHIAW ${ }^{2}$ and Wirot LIKITTRAKULWONG ${ }^{1}$ \\ ${ }^{I}$ Faculty of Food and Agricultural Technology, Pibulsongkram Rajabhat University, \\ Phitsanulok 65000, Thailand \\ ${ }^{2}$ Institute of Food Research and Product Development, Kasetsart University, Bangkok 10900, Thailand
}

('Corresponding author's e-mail: khongsak@live.psru.ac.th)

Received: 26 March 2018, Revised: 19 August 2018, Accepted: 20 September 2018

\begin{abstract}
Sugar profile, antioxidant properties, DNA damages, and in vitro predicted glycaemic index ( $p \mathrm{GI}$ ) of palm sugars (syrup and powder) were investigated in comparison with refined cane sugar. It was found that palm sugars exhibited better nutritional qualities than refined cane sugars. Palm sugars in both syrup and powder forms showed similar results, except in some properties. They contained a high content of fructose and glucose. They also exhibited better antioxidant properties, as evidenced by the high content of phenolic compounds and flavonoids. This contributed to their great antioxidant activities when assessed by DPPH radical scavenging activity and FRAP assay. The addition of palm sugar extracts to the reaction mixture effectively protected against DNA damage. For $p \mathrm{GI}$, the mixture of corn starch and palm sugars showed slow digestion rate and, consequently, lower $p$ GI values than those of refined cane sugars. Nutritional and functional properties of palm sugars were thought to be influenced by their retained phytonutrients, as they were processed under mild conditions.
\end{abstract}

Keywords: Palm sugar, palmyra palm, antioxidant, DNA damage, glycaemic index

\section{Introduction}

Borassus flabellifer Linn. (palmyra palm), belonging to the Arecaceae family, grows wild from the Persian Gulf to the Cambodian-Vietnamese border, and is commonly cultivated in India, Southeast Asia, and Malaysia, and occasionally in other warm regions, including Hawaii and southern Florida. Palms are tree crops which benefit the environment ecologically, as they restore damaged soil, requiring very little water in the process. In addition to the sweet sap from the inflorescence and the many products of the leaves, trunk, and underground seedlings, a thin orange pulp coating the fibers of the mature fruit is consumed fresh or dried as a paste. The large seeds, when immature, before the shell hardens, contain jelly-like kernels esteemed for food [1,2]. Hence, their socio-economic importance can be critical for the rural poor.

Most palmyra palms have been tapped in order to produce fresh or fermented juices, syrup, and sugars. They produce sugar yields that are higher than sugarcane production [3]. For the traditional production of palm sugar, a large volume of filtered palm sap is transferred into a big wok, where the filtered palm saps are heated on a wood fired stove for a few hours at about $100{ }^{\circ} \mathrm{C}$ until it becomes concentrated to obtain a typical aroma. Mainly, 2 major reactions occur during the heating process of palm sap; Maillard reaction and caramelization. After the heating process, the palm sap liquid is poured into bamboo molds to form pure solid palm sugar which is ready for consumption [4,5]. Palm sugars have been used as a traditional sweetener for thousands of years in Asia. It is now gaining popularity globally because of its natural source, minimal processing, and healthiness. One of the major health claims is its glycaemic index (GI). Palm sugars are normally marketed as low GI foods, though only a few published papers are evidenced [6]. In addition, palm sugars are minimally processed, unrefined, and contain natural 
http://wjst.wu.ac.th

sugars. They could present nutritionally significant quantities of minerals and vitamins, including antioxidant properties [7]. It has been reported that palm sugar (gula anau) exhibits the highest level of antioxidant activity compared to various types of cane sugars, having an antioxidant activity equivalent to $1.7 \mathrm{mg}$ of vitamin $\mathrm{C}$ per $1 \mathrm{~g}$ of sugar [8]. Recent publications have highlighted that unrefined sugars, as parts of non-centrifugal cane sugars, have nutritionally and functionally significant quantities of minerals, vitamins, and phenolics, among other constituents, as well as antioxidant capacities [9].

In view of the importance of palm sugars as local products for the local poor, as well as their nutritional and functional properties, this paper aimed to determine the functional properties, including nutritional qualities, of palm sugars produced by traditional methods, in both syrup and powder forms.

\section{Materials and methods}

\section{Materials}

Fresh palm sap was collected from farmers in Phitsanulok province, Thailand. It was transported in ice boxes and processed immediately to avoid any quality changes or fermentation. Initial total soluble solid and $\mathrm{pH}$ of fresh palm sap were found to be $15-17^{\circ}$ Brix and $4.5-5.5$, respectively. Palm sugar syrup and powder were produced from fresh palm sap, using traditional open pan heating [10]. Commercial refined cane sugar (Mitr Phol Sugar Corp Ltd.) was used for comparison. The manufacturer declared $100 \%$ refined cane sugar. All chemicals used were AR grade and purchased from SigmaAldrich (Thailand distributor).

\section{Production of palm sugar syrup}

Fresh palm sap $(10 \mathrm{~L})$ was heated using high heat $\left(95-100{ }^{\circ} \mathrm{C}\right)$ in an open wok and simultaneously stirred until the total soluble solids reached $70^{\circ}$ Brix. High fructose corn syrup (HFCS-55, containing 55 $\%$ fructose and $45 \%$ glucose) was then added to the syrup at $7 \mathrm{~g} / 100 \mathrm{~g}$ syrup as an anti-crystallization agent. Refined soybean oil $(0.1 \mathrm{~g} / 100 \mathrm{~g}$ syrup) was also added as an anti-foaming agent. The syrup was hot filled into glass bottles $(50 \mathrm{~mL})$ and hermetically sealed by metal caps. The products were kept in room temperature until analysis.

\section{Production of palm sugar powder}

Fresh palm sap $(10 \mathrm{~L})$ was heated using high heat $\left(95-100{ }^{\circ} \mathrm{C}\right)$ at the beginning, and then gentle heat $\left(70-75^{\circ} \mathrm{C}\right)$ in the open wok, and simultaneously stirred until it became dried solids. The dried solids were further dried in an air-forced oven (Memmert UN110) at $50{ }^{\circ} \mathrm{C}$ for $6-7 \mathrm{~h}$ until the water activity $\left(a_{w}\right)$ reached below 0.6, which is the maximum value for powdered foods. Palm sugar powder was sieved through an 80 mesh screen and packed in a vacuum sealed opaque container until analysis.

\section{Sugar profile}

Sugar profile was determined using a HPLC (Agilent 1100 series) with a Zorbax Carbohydrate column and a refractive index detector. The mobile phase was a solution of acetonitrile and water (80:20), pumped at a flow rate of $1.5 \mathrm{~mL} / \mathrm{min}$. The samples were prepared by making appropriate dilutions with distilled water. All sample solutions were passed through a $0.45 \mu \mathrm{m}$ nylon syringe filter to remove particulates prior to HPLC analysis. D-glucose, D-fructose, and sucrose (HPLC grade) were used as external standards. The calibration curve of each sugar was plotted between peak areas and concentrations $[11,12]$.

\section{Antioxidant properties}

Sample extraction

The samples were extracted using distilled water [13]. Samples of $5 \mathrm{~g}$ were mixed with distilled water and stirred for $2 \mathrm{~h}$. Then, the mixture was filtered through Whatman No.4 filter paper. The serial dilution of the extract was made to obtain the desired concentration. The extracts were kept frozen until use. 
http://wjst.wu.ac.th

\section{Total phenolic compounds}

Phenolic content in each sample was carried out according to the method described previously [14] with some modifications. The extract $(0.5 \mathrm{~mL})$ was mixed with $0.5 \mathrm{~mL}$ of distilled water. Thereafter, 0.5 $\mathrm{mL}$ of Folin-Ciocalteu reagent (1:1 with water) and $2.5 \mathrm{~mL}$ of $2 \% \mathrm{Na}_{2} \mathrm{CO}_{3}$ solution in distilled water were added. The mixture was mixed thoroughly and placed in the dark for $40 \mathrm{~min}$. After that, the absorbance was recorded at $765 \mathrm{~nm}$ (GENESYS ${ }^{\mathrm{TM}} 10 \mathrm{~S}$ spectrophotometer), and the phenolic content was calculated from the standard curve of gallic acid.

\section{Total flavonoids}

The determination of flavonoids was performed according to the colorimetric assay [15]. The extract $(0.5 \mathrm{~mL})$ was diluted with $2.5 \mathrm{~mL}$ of distilled water. After the addition of $150 \mu \mathrm{L}, 5 \% \mathrm{NaNO}_{2}$ solution, the mixture was left to stand for $6 \mathrm{~min}$ at room temperature and, then another $5 \mathrm{~min}$ after adding $300 \mu \mathrm{L}$ of $10 \% \mathrm{AlCl}_{3} \cdot 6 \mathrm{H}_{2} \mathrm{O}$ solution. The mixture was made up to $5 \mathrm{~mL}$ with distilled water after adding $1 \mathrm{~mL}$ of $1 \mathrm{M} \mathrm{NaOH}$. The solution was thoroughly vortexed, and the absorbance was measured at $510 \mathrm{~nm}$ (GENESYS ${ }^{\text {TM }} 10 \mathrm{~S}$ spectrophotometer) with rutin as a reference standard.

\section{DPPH radical scavenging activity}

DPPH radical scavenging activity of the palm sugar extracts were measured according to the method described earlier [16]. Briefly, $400 \mu \mathrm{L}$ of palm sugar extract was mixed with $2 \mathrm{~mL}$ of DPPH solution $(0.12 \mathrm{mM}$ in $95 \%$ ethyl alcohol). The mixtures were shaken vigorously and left to stand for 30 min in the dark and the absorbance measured at $517 \mathrm{~nm}$ (GENESYS ${ }^{\text {TM }}$ 10S spectrophotometer). The capacity to scavenge the DPPH radical was calculated using the following equation: $(\%)=\left[\left(\mathrm{A}_{\mathrm{o}}-\right.\right.$ $\left.\left.\left.A_{1}\right) / A_{o}\right)\right] \times 100$, where, $A_{o}$ is the absorbance of the control reaction and $A_{1}$ is the absorbance of the sample itself.

\section{FRAP assay}

Ferric reducing antioxidant power (FRAP) was assayed according to the method described elsewhere [17] with slight modifications. The FRAP reagent containing $20 \mathrm{mM} \mathrm{FeCl}, 10 \mathrm{mM}$ TPTZ (2,4,6-tripyridyl-s-triazine) solution in $40 \mathrm{mM} \mathrm{HCl}$, and $0.3 \mathrm{M}$ acetate buffer $(\mathrm{pH} 3.6)$ in the ratio of 1:1:10 by volume was freshly prepared. The extracts $(100 \mu \mathrm{L})$ and $4.9 \mathrm{~mL}$ of FRAP reagent were transferred into vials and incubated at $37{ }^{\circ} \mathrm{C}$ for $10 \mathrm{~min}$. Absorbance at $593 \mathrm{~nm}$ (GENESYS ${ }^{\mathrm{TM}} 10 \mathrm{~S}$ spectrophotometer) was measured relative to a reagent blank also incubated at $37{ }^{\circ} \mathrm{C}$. The FRAP data for samples were determined against a standard of known FRAP value, $\mathrm{FeSO}_{4}$. The results were expressed as $\mathrm{mg} \mathrm{FeSO}_{4} / 100 \mathrm{~g}$ dry weight.

\section{DNA damage}

DNA damage was tested using the aqueous extracted palm sugars (syrup and powder forms) at various concentrations (20 - $100 \mathrm{~g} / 100 \mathrm{~g}$ samples) and DNA obtained from palm sugar leaves [18]. DNA was extracted from the leaves using the method described elsewhere [19]. The DNAs (1 ng) were stored at $-20^{\circ} \mathrm{C}$. The presence of DNA was confirmed by gel electrophoresis $(1.5 \%)$. The site specific hydroxyl radical-mediated DNA strand breaks were measured as described earlier [20] with some modifications. Briefly, $0.5 \mu \mathrm{g}$ DNA was incubated with $1 \mu \mathrm{L}$ of $1 \mathrm{mM} \mathrm{FeSO}_{4}, 1 \mu \mathrm{L}$ of $6 \% \mathrm{H}_{2} \mathrm{O}_{2}$, and $3 \mu \mathrm{L}$ of aqueous extracts of palm sugars, and the final volume was made up to $15 \mu \mathrm{L}$ with $50 \mathrm{mM}$ phosphate buffer (pH 7.0). The mixture was incubated in a water bath at $37{ }^{\circ} \mathrm{C}$ for $30 \mathrm{~min}$. After incubation, the sample was immediately loaded into $1.5 \%$ agarose gel along with $3 \mu \mathrm{L}$ ethidium bromide, containing $40 \mathrm{mM}$ Tris, 20 $\mathrm{mM}$ sodium acetate, and $2 \mathrm{mM}$ EDTA, and electrophoresed in a horizontal slab apparatus in Tris/boric/EDTA gel buffer. The gel was then photographed under UV light.

\section{In vitro predicted glycaemic index ( $p$ GI)}

The $p$ GI values of palm and refined cane sugars were indirectly assessed by in vitro enzymatic digestion of corn starch and sugar mixtures following the method described earlier [6]. Sugar samples 
http://wjst.wu.ac.th

were mixed thoroughly with corn starch (Sigma-Aldrich, Thailand distributor) at $30 \mathrm{~g} / 100 \mathrm{~g}$ dry basis. Thus, total starch of the samples was estimated as $70 \mathrm{~g} / 100 \mathrm{~g}$ dry basis. The rapid in vitro digestibility assay based on glucometry was used for the digestion and modelling of starch digestograms [21]. Briefly, about $0.5 \mathrm{~g}$ of the ground sample was treated with artificial saliva containing porcine $\alpha$-amylase (Sigma A-3176 Type VI-B) before pepsin (Sigma P-6887; pH 2.0) was added and incubated at $37{ }^{\circ} \mathrm{C}$ for 30 min in a reciprocating water bath $(85 \mathrm{rpm})$. The digesta was neutralized with $\mathrm{NaOH}$ before adjusting the $\mathrm{pH}$ to 6 (sodium acetate buffer) prior to the addition of pancreatin (Sigma P1750) and AMG (Sigma A-7420). The mixture was incubated for $4 \mathrm{hr}$, during which the glucose concentration in the digesta was measured with an Accu-Check ${ }^{\circledR}$ Performa $^{\circledR}$ glucometer at specific periods $(0-240 \mathrm{~min})$. Digested starch was calculated and the digestogram (digested starch at a specific time period) was modeled using a modified first-order kinetic model, Eq. (1), as described elsewhere [22].

$D_{t}=D_{0}+D_{\infty-0}(1-\exp [-K t])$

where $D_{t}(\mathrm{~g} / 100 \mathrm{~g}$ dry starch $)$ is the digested starch at time $t, D_{0}$ is the digested starch at time $t=0, D_{\infty}$ is the digestion at infinite time $\left(D_{0}+D_{\infty-0}\right)$, and $K$ is the apparent rate constant $\left(\mathrm{min}^{-1}\right)$.

The Microsoft Excel Solver ${ }^{\circledR}$ was used to compute the parameters of the model by minimizing the sum of squares of residuals (SUMSQ) and constraining $D_{\infty} \leq 100 \mathrm{~g}$ per $100 \mathrm{~g}$ dry starch and $D_{0} \geq 0 \mathrm{~g}$ per $100 \mathrm{~g}$ dry starch. In addition to the coefficient of determination $\left(r^{2}\right)$, the predictive ability of the models was assessed with the mean relative deviation modulus (MRDM).

The hydrolysis index (HI) of each sample was calculated by dividing the area under its digestogram by the area under the digestogram of fresh white bread [23], which was calculated to be about 6,200 min $\mathrm{g} / 100 \mathrm{~g}$ dry starch from 0 - $240 \mathrm{~min}$. Starch digestion at $90 \mathrm{~min}$ (H90) and HI were used to calculate predicted GI $(p G I)$. The average $p G I\left(p G I_{\mathrm{AVG}}\right)$ for each sample was defined as the average of $p G I_{\mathrm{H} 90}$ and $p G I_{\mathrm{HI}}$. Each sample was analyzed in triplicate.

\section{Statistical analysis}

Analysis of variance (ANOVA), test of significance, and comparison of means, using Tukey's test, were performed using Minitab $^{\circledR}$ ver. 17, with a confidence level of $95 \%$. The samples were randomized for all the analyses described above.

\section{Results and discussion}

Aspects of production of palm sugars

Palm sugars can be produced in various forms. Fresh palm sap has a short shelf life, so it can be extended using common thermal processing, such as pasteurization or sterilization. For thermally processed palm sap, cloudiness could develop during storage. This quality deterioration might be caused by either the dispersion of undissolved particles, normally formed through the interaction between polyphenol compounds and proteins, or brown pigment formation. Clarification using some additives, such as polyvinylpolypyrrolidone, bentonite, gelatin, and chitosan, could be applied to improve the quality $[10,14]$. In terms of palm syrup, clarifying agents could also be used as well. However, the most important problem associated with palm sugar syrup is crystallization. Without proper control, crystallization normally occurs within a couple of days after storage. Several approaches could be used to prevent crystallization. The system must have sufficient low molecular mobility (high viscosity) so that the molecules cannot form into crystals, or crystallization must be inhibited by the addition of inhibiting ingredients, such as corn syrup and other sugars. Crystallization is inhibited kinetically through proper formulation. The shelf life of products in which crystallization is undesired is often directly related to the induction time for nucleation at the storage conditions. Thus, nucleation must be substantially inhibited to prevent undesired crystallization [24]. This paper used high fructose corn syrup as the crystallization inhibiting ingredient in palm sugar syrup. 
Further heating of palm sugar syrup will reduce $a_{w}$ and increase viscosity. Palm sugars, in the forms of cubes/pieces or powders, may be produced by evaporating palm sap until the desired $a_{w}$ is reached $\left(a_{w}\right.$ of less than 0.60 is required for powdered food). Solid forms of palm sugars are very hygroscopic. Therefore, proper packaging (e.g., with food grade moisture absorbers) and storage conditions (e.g., cool and dry) are required. In addition, bulking agents, such as maltodextrin, may be used in the solid forms of palm sugars.

\section{Sugar profile}

Table 1 shows the sugar contents of palm sugar samples (syrup and powder) in comparison with commercial refined cane sugars.

Table 1 Sugar contents of the palm sugars in comparison with commercial refined cane sugars.

\begin{tabular}{lllll}
\hline Samples & $\begin{array}{l}\text { Glucose } \\
(\mathbf{g} / \mathbf{1 0 0} \mathbf{g} \text { DW) }\end{array}$ & $\begin{array}{l}\text { Fructose } \\
(\mathbf{g} / \mathbf{1 0 0} \mathbf{g} \text { DW) }\end{array}$ & $\begin{array}{l}\text { Sucrose } \\
\mathbf{( g / 1 0 0} \mathbf{g} \text { DW) }\end{array}$ & $\begin{array}{l}\text { Total sugars } \\
(\mathbf{g} / \mathbf{1 0 0} \mathbf{g ~ D W})\end{array}$ \\
\hline Palm sugar syrup & $5.91 \pm 0.25 \mathrm{a}$ & $6.64 \pm 0.17 \mathrm{a}$ & $65.26 \pm 0.73 \mathrm{c}$ & $77.81 \pm 1.16 \mathrm{~b}$ \\
Palm sugar powder & $4.46 \pm 0.02 \mathrm{~b}$ & $4.41 \pm 0.01 \mathrm{~b}$ & $68.76 \pm 0.33 \mathrm{~b}$ & $77.63 \pm 0.45 \mathrm{~b}$ \\
Refined cane sugars & $0.23 \pm 0.01 \mathrm{c}$ & $2.06 \pm 0.21 \mathrm{c}$ & $96.42 \pm 1.06 \mathrm{a}$ & $98.71 \pm 0.38 \mathrm{a}$ \\
\hline
\end{tabular}

Remark: Means with different letters within a column are significantly different $(\mathrm{p} \leq 0.05)$.

From Table 1, total sugar contents of both palm sugars were similar. They were significantly different $(\mathrm{p}<0.05)$ from refined cane sugars, which are mostly composed of sucrose. Palm sugars are normally produced by evaporating palm sap in an opened pan until the concentrated paste is obtained. It does not undergo any purification process, or use any synthetic chemicals, so it can provide sugars with potential nutritional benefits [7]. Palm sugars have higher reducing sugar content than refined cane sugars, or industrially manufactured sugars. It has been reported that very intense heating of palm sugars, especially at high temperature and for long heating time, could accelerate the hydrolysis of sucrose yielding reducing sugars. However, high reducing sugar content presented in sugar also influences the browning color of sugar afterward, due to the Maillard reaction [10]. Thus, low reducing sugar in refined cane sugars, compared to palm sugars, might be due to the chemical refining process, which could eliminate the reducing sugar. In addition, some authors reported that the difference of total sugar and reducing sugar content might be due to the effect of contamination from micro-organisms in sugar. The micro-organisms can convert sucrose to glucose and fructose (invert sugar) and, finally, to organic acids or alcohols [25].

\section{Antioxidant properties}

Antioxidant properties of the palm sugar extracts, as indicated by total phenolic compounds, total flavonoids, DPPH radical scavenging activity, and FRAP assay, are shown in Table 2. 
http://wjst.wu.ac.th

Table 2 Antioxidant properties of the palm sugars in comparison with commercial refined cane sugars.

\begin{tabular}{lllll}
\hline Samples & $\begin{array}{l}\text { Total phenolic } \\
\text { contents (mg gallic } \\
\text { acid/100 g DW) }\end{array}$ & $\begin{array}{l}\text { Total flavonoid } \\
\text { contents }(\mathbf{m g} \\
\text { rutin/100 g DW) }\end{array}$ & $\begin{array}{l}\text { DPPH radical } \\
\text { scavenging } \\
\text { activity }(\%)\end{array}$ & $\begin{array}{l}\text { FRAP (mg } \\
\text { FeSO } / \mathbf{1 0 0} \text { g } \\
\text { DW) }\end{array}$ \\
\hline Palm sugar syrup & $520.47 \pm 6.35 \mathrm{a}$ & $223.76 \pm 3.94 \mathrm{a}$ & $67.32 \pm 1.48 \mathrm{a}$ & $9.57 \pm 0.08 \mathrm{a}$ \\
Palm sugar powder & $383.39 \pm 3.24 \mathrm{~b}$ & $188.23 \pm 3.81 \mathrm{~b}$ & $54.73 \pm 2.01 \mathrm{~b}$ & $6.68 \pm 1.02 \mathrm{~b}$ \\
Refined cane sugars & $35.58 \pm 1.27 \mathrm{c}$ & $11.52 \pm 1.68 \mathrm{c}$ & $2.18 \pm 0.07 \mathrm{c}$ & $1.08 \pm 0.05 \mathrm{c}$ \\
\hline
\end{tabular}

Remark: Means with different letters within a column are significantly different $(\mathrm{p} \leq 0.05)$.

It has been reported that palm sugars contain considerably high amounts of polyphenols and flavonoids [7,13]. Sugarcane was reported to be a promising potential source of flavonoid compounds, which are a widely distributed group of phenolic compounds in plants [26]. Phenolic substances and flavonoids were suggested to be important antioxidants in brown sugar and other sugarcane products [27]. In this study, palm sugar syrup exhibited the highest amount of total phenolic compounds and flavonoids, followed by palm sugar powder and refined cane sugar, respectively. Industrial refining processes of refined cane sugars caused the vast decrease in active compounds. Total phenolic compounds and flavonoids in palm sugar powders were found to be lower than those in syrup. This was due to the longer heating time of palm sugar powders. Phenolic compounds were naturally found in the palm sap itself. They also increased during the heating process, due to the release of bound polyphenol [10]. In addition, it has been reported that jaggery and brown sugars have higher phenolic content compared to white and refined sugar. This was probably due to the minimal chemical processing in the manufacture of jaggery and brown sugar, which could retain more polyphenols. The phenolic compounds impart color, as well as taste, to sugars [28].

The results for DPPH radical scavenging activity and FRAP values of palm sugars in comparison with refined cane sugars show similar trends to phenolic and flavonoid contents. The increase in free radical scavenging activity of the extracts is in agreement with the higher active compounds. Highly processed sugars, such as refined cane sugars, showed a decrease in antioxidant properties. Polyphenol compounds are normally found in plant saps, especially palm sap, maple sap, and coconut sap [29,30]. The antioxidant activity of polyphenol compounds is clearly related to free radical-scavenging and hydrogen-donation ability. A positive correlation between antioxidant activity and polyphenol content has been reported [31]. In addition, Maillard reaction products (MRPs) and caramelization products (CPs) formed during the production of palm sugar syrup are also responsible for the antioxidant activity of palm sugar syrup. Several authors have proven that these MRPs and CPs possess antioxidant activity in food products [32]. Hence, the high polyphenol content and MRPs, as well as CP formations of palm sugars (both syrup and powder forms), are responsible for high DPPH radical scavenging activity and FRAP values.

Because of their antioxidant properties, there has been a growing interest in the value of polyphenols in palm sugars, as well as other naturally processed sugars, such as non-centrifugal sugar (NCS). Scientific research has confirmed significant positive health effects of NCS and its precursor products, including their immunological effects, anti-toxicity, and cytoprotective effects, anticariogenic effects, and diabetes and hypertension effects [33].

\section{DNA damage}

Palm sugar extracts were used in the site-specific DNA damage assay to study the protective effects of palm sugar extracts on hydroxyl radical-mediated DNA strand break. Incubation of DNA extracted from the palm leaves with $\mathrm{FeSO}_{4}$ and $\mathrm{H}_{2} \mathrm{O}_{2}$ for $30 \mathrm{~min}$ in a water bath resulted in producing hydroxyl ions, thereby indicating that both single-strand and double-strand DNA breaks can be induced by 
http://wjst.wu.ac.th

$\mathrm{FeSO}_{4} / \mathrm{H}_{2} \mathrm{O}_{2}$ at the indicated concentrations and incubation time. The gel pattern of DNA exposed to $\mathrm{FeSO}_{4}$ and $\mathrm{H}_{2} \mathrm{O}_{2}$, in the presence and the absence of palm sugar extracts is presented in Figure 1.

(a) Palm sugar syrup

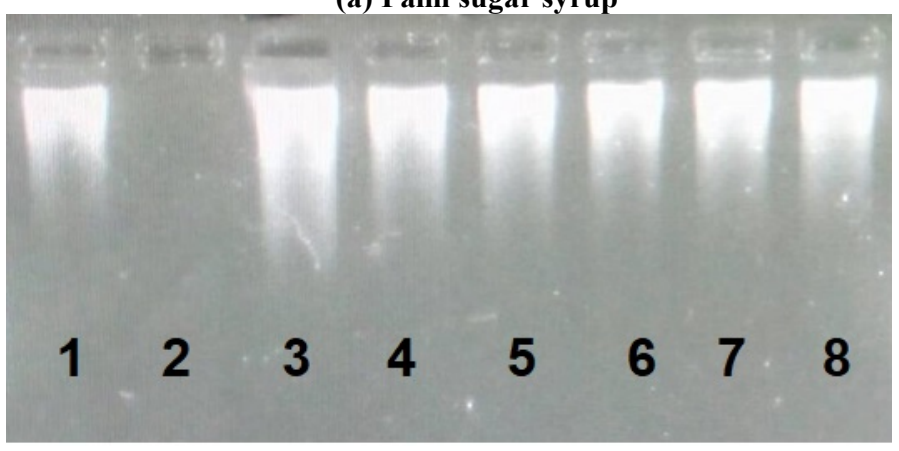

(b) Palm sugar powder

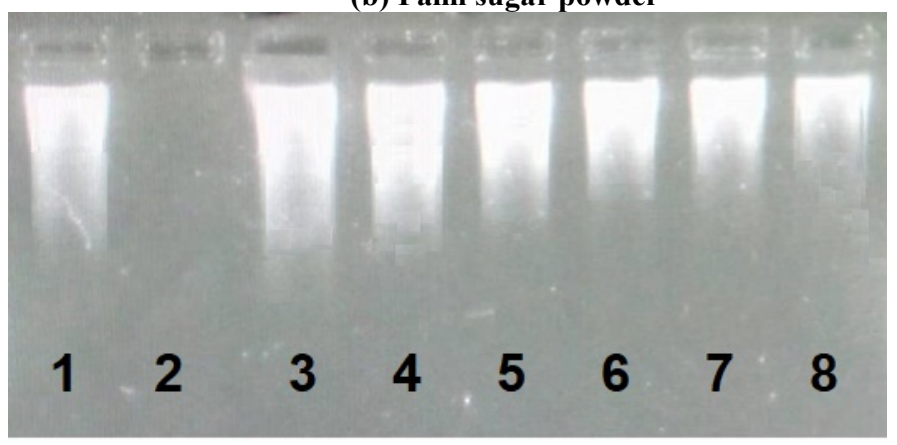

Figure 1 DNA damages induced by $\mathrm{FeSO}_{4}$ and $\mathrm{H}_{2} \mathrm{O}_{2}$ in the presence of palm sugar extracts from (a) syrup and (b) powder. The lanes (1 - 2) are positive and negative controls, lane 3 is without the addition of palm sugar extracts, and lanes $4-8$ are with the addition of palm sugar extracts at 20,40,60,80, and $100 \mathrm{~g} / 100 \mathrm{~g}$, respectively.

From Figure 1, positive control (lane 1) showed a smear band, while negative control (lane 2) did not show any smear band, which indicated suitable conditions. The longer smear band indicated more damaged DNA, as shown in lane 3 in which no palm sugar extract was added. Lanes $4-8$ showed the smear band of damaged DNA with the presence of palm sugar extracts from $20-100 \mathrm{~g} / 100 \mathrm{~g}$. It is clear that higher concentrations of the extracts showed more effective protection against DNA damage, as indicated by shorter or smaller smear bands. The aqueous extract from palm sugar syrup (Figure 1a) showed slightly better DNA damage protection than its counterpart (Figure 1b). Hydroxyl radicals generated by the Fenton reaction are known to cause oxidatively induced breaks in DNA strands to yield its fragmented forms. The free radical scavenging activity of palm sugars was studied on genomic DNA. The treatment of supercoiled DNA with Fenton's reagent directed the alteration of DNA to an open circular form. The addition of extracts to the reaction mixture substantially decreased the DNA strand scission and retained the supercoiled form, thus, effectively protecting DNA. DNA damage protecting activity of palm sugars has not been reported previously. However, extracts from sugarcane have been reported to exhibit strong ability to protect against DNA damage induced by hydroxyl radical generated in Fenton reaction [18]. It has also been reported that sugarcane juice has a protective role against DNA damage caused by radiation [34] and hydroxyl radical, which might be due to the chelating activity on 
http://wjst.wu.ac.th

iron or hydroxyl radical scavenging or both [35]. The powerful antioxidant activity of palm sugar extracts is given by the presence of substances with hydroxyls. In this context, flavonoids possess an ideal structure for the scavenging of free radicals, since they present a number of hydroxyls able to donate hydrogen atoms and act as an important antioxidant agent [36]. In fact, polyphenols are an important group of active compounds, which are considered to be the most active antioxidant derivatives in plants [37]. However, it has been shown that the antioxidant activity does not necessarily follow the phenolic content. Antioxidant activity is generally the result of the combined activity of a wide range of compounds [38].

\section{In vitro $p \mathrm{GI}$}

Figure 2.

The digestograms of starch sugar mixtures showing the digested starch over times are shown in

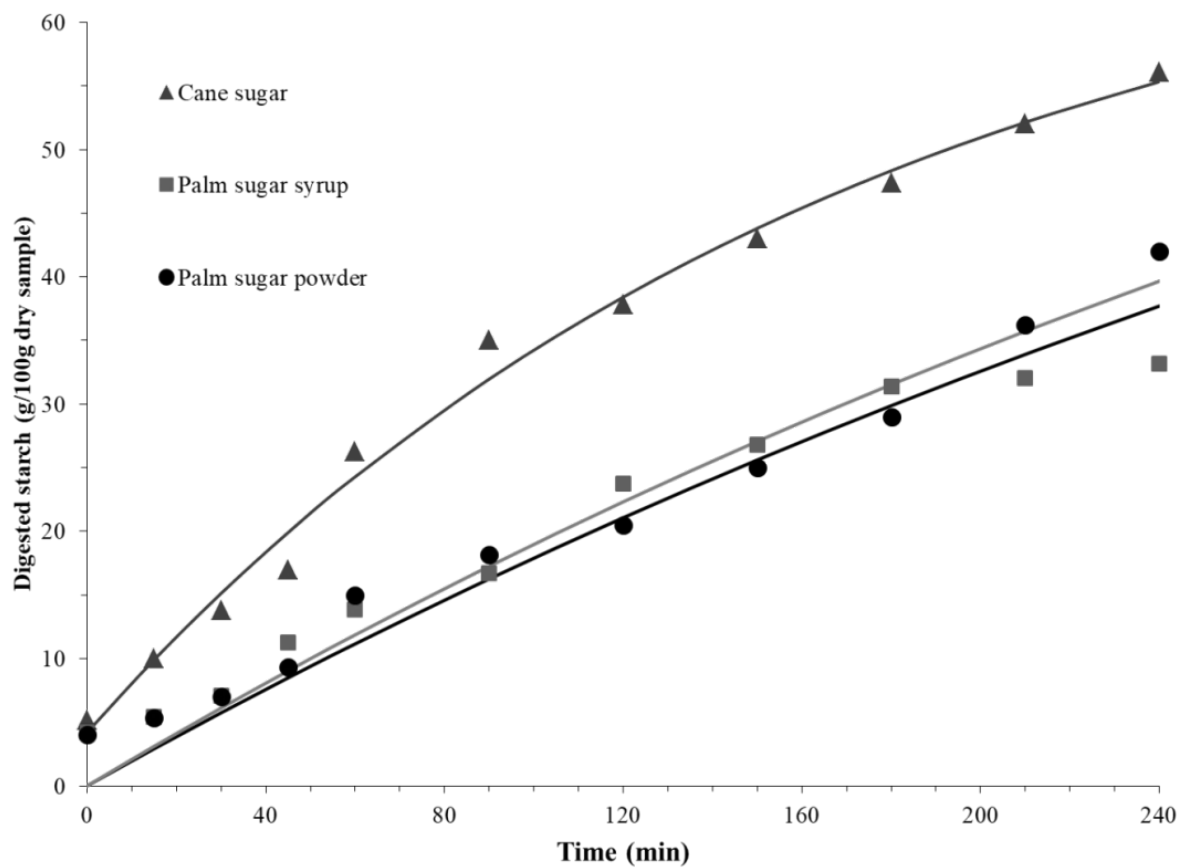

Figure 2 Digestograms of the corn starch and sugar mixtures.

The digestion rates of both palm sugars were significantly lower than that of refined cane sugars. This was confirmed by the numerical data and model parameters as shown in Table 3.

Table 3 Model parameters $\left(D_{0}\right.$ and $\left.K\right)$, hydrolysis index $(H I)$, and predicted glycaemic index $(p G I)$ of the samples.

\begin{tabular}{lllll}
\hline Samples & $\begin{array}{l}\boldsymbol{D}_{\mathbf{o}} \\
(\mathbf{g} / \mathbf{1 0 0} \mathbf{g} \mathbf{D W})\end{array}$ & $\begin{array}{l}\boldsymbol{K} \mathbf{x ~ 1 0} \mathbf{~ 0}^{-3} \\
\mathbf{m i n}^{-1} \mathbf{)}\end{array}$ & $\boldsymbol{H I}$ & $\boldsymbol{p G I}$ \\
\hline Palm sugar syrup & $0.00 \mathrm{~b}$ & $2.11 \pm 0.03 \mathrm{~b}$ & $83.33 \pm 0.94 \mathrm{~b}$ & $70.05 \pm 0.35 \mathrm{~b}$ \\
Palm sugar powder & $0.00 \mathrm{~b}$ & $2.03 \pm 0.09 \mathrm{~b}$ & $80.82 \pm 2.99 \mathrm{~b}$ & $69.11 \pm 1.12 \mathrm{~b}$ \\
Refined cane sugars & $3.28 \pm 1.31 \mathrm{a}$ & $6.37 \pm 0.71 \mathrm{a}$ & $136.7 \pm 1.50 \mathrm{a}$ & $91.13 \pm 0.45 \mathrm{a}$ \\
\hline
\end{tabular}

Remark: Means with different letters within a column are significantly different $(\mathrm{p} \leq 0.05)$. 
http://wjst.wu.ac.th

The modified first-order kinetic model proved suitable in describing the digestograms $\left(r^{2}=0.97\right.$ 0.99 ; $\mathrm{MRDM}=26.69-75.61 \%$; SUMSQ $=3.93$ - 22.82). From Table 3, the $p G I$ values of starch mixtures from refined cane sugars are significantly higher than those from palm sugars which exhibited medium $p G I$ values $(69.11$ - 70.05). Clinical trials have suggested that low GI diets result in modest improvements in overall blood glucose control, reduced insulin secretion, and lowered blood lipid concentrations. These make low GI foods important for obesity, diabetes, and their dietary management [39].

Palm sugars, including similar types, e.g., coconut sugars, have been reported to exhibit lower GI values than refined cane sugars. The GI values of coconut sap and sugars were found to be in the low category, $35 \pm 4$ and $42 \pm 4$ [40]. The GI of wheat flour and coconut/palm sugar mixtures were reported to be about 61 (medium category), as evaluated by an in vitro method [6]. Palm sugars contain significant amounts of other sugars, such as fructose and glucose, rather than only sucrose, as shown before. Although the major sugar component in palm sugars are sucrose, similar to cane sugars, the starch digestion rate and $p G I$ values were found to be lower. This could be influenced by palm sugars being sugars with minimal processing, and their natural forms are complex and contain other ingredients. Palm sugars were reported to contain significant amounts of dietary fiber, especially inulin [41]. These could play an important role in lowering the GI values of palm sugars when compared to refined cane sugars, which contain almost pure sucrose.

\section{Conclusions}

Palm sugar is a valuable nutritional product which is produced by dehydrating palm sap until it reaches the desired solid concentrations. It can be produced in various forms, such as syrup and powder. As palm sugars are processed minimally, they retain natural phytonutrients, which possess many biological functions with beneficial effects on human health. These can be evidenced by considerably high amounts of polyphenols and flavonoids, high antioxidant properties, and the ability to protect DNA from damage. Palm sugars also benefit in terms of $p \mathrm{GI}$ when used in carbohydrate foods. There is increasing recognition of the negative impacts of current global food consumption patterns, and natural and organic products are increasingly popular. This opens an opportunity for the revival of minimally processed sugars or non-centrifugal sugars, such as palm sugars. However, it should be noted that consumption of large amounts of any sugars could lead to health risks.

\section{Acknowledgements}

This research was financially supported by the Thailand Research Fund (TRF) - Grant No. RDG5950070.

\section{References}

[1] J Mogea, B Seibert and W Smits. Multipurpose palms: The sugar palm (Arenga pinnata (Wurmb) Merr.). Agrofor. Syst. 1991; 13, 111-29.

[2] JF Morton. Notes on distribution, propagation, and products of Borassus Palms (Arecaceae). Econ. Bot. 1988; 42, 420-41.

[3] MR Ishak, SM Sapuan, Z Leman, MZA Rahman, UMK Anwar and JP Siregar. Sugar palm (Arenga pinnata): Its fibres, polymers and composites. Carbohydr. Polym. 2013; 91, 699-710.

[4] CW Ho, WMW Aida, MY Maskat and H Osman. Changes in volatile compounds of palm sap (Arenga pinnata) during the heating process for production of palm sugar. Food Chem. 2007; 102, 1156-62.

[5] CW Ho, WMW Aida, MY Maskat and H Osman. Effect of thermal processing of palm sap on the physico-chemical composition of traditional palm sugar. Pakistan J. Biol. Sci. 2008; 11, 989-95.

[6] K Srikaeo and R Thongta. Effects of sugarcane, palm sugar, coconut sugar and sorbitol on starch digestibility and physicochemical properties of wheat based foods. Int. Food Res. J. 2015; 22, 9239. 
http://wjst.wu.ac.th

[7] I Victor and V Orsat. Characterization of Arenga pinnata (Palm) Sugar. Sugar Tech. 2018; 20, $105-$ 9.

[8] J Sia, HB Yee, JH Santos and MKA Abdurrahman. Cyclic voltammetric analysis of antioxidant activity in cane sugars and palm sugars from Southeast Asia. Food Chem. 2010; 118, 840-6.

[9] WR Jaffé. Nutritional and functional components of non centrifugal cane sugar: A compilation of the data from the analytical literature. J. Food Compos. Anal. 2015; 43, 194-202.

[10] P Naknean and M Meenune. Impact of clarification of palm sap and processing method on the quality of palm sugar syrup (Borassus flabellifer Linn.). Sugar Tech. 2015; 17, 195-203.

[11] P Naknean and M Meenune. Quality profiles of pasteurized palm sap (Borassus flabellifer Linn.) collected from different regions in Thailand. Walailak J. Sci. \& Tech. 2016; 13, 165-76.

[12] P Naknean. Improvement in shelf life and safety of pasteurized palm sap (Borassus flabellifer Linn.) by the addition of nisin. J. Food Saf. 2013; 33, 515-25.

[13] S Kongkaew, M Chaijan and S Riebroy. Some characteristics and antioxidant activity of commercial sugars produced in Thailand. KMITL Sci. Tech. J. 2014; 14, 1-9.

[14] P Naknean, N Juntorn and T Yimyuan. Influence of clarifying agents on the quality of pasteurised palmyra palm sap (Borassus flabellifer Linn.). Int. J. Food Sci. Tech. 2014; 49, 1175-83.

[15] M Liu, XQ Li, C Weber, CY Lee, J Brown and RH Liu. Antioxidant and antiproliferative activities of raspberries. J. Agric. Food Chem. 2002; 50, 2926-30.

[16] G Yen and P Hsieh. Antioxidative activity and scavenging effects on active oxygen of xylose-lysine Maillard reaction products. J. Sci. Food Agr. 1995; 67, 415-20.

[17] IFF Benzie and JJ Strain. The ferric reducing ability of plasma (FRAP) as a measure of "antioxidant power": The FRAP assay. Anal. Biochem. 1996; 239, 70-6.

[18] SR Abbas, SM Sabir, SD Ahmad, AA Boligon and ML Athayde. Phenolic profile, antioxidant potential and DNA damage protecting activity of sugarcane (Saccharum officinarum). Food Chem. 2014; 147, 10-6.

[19] M Li and DJ Midmore. Estimating the genetic relationships of Chinese water chestnut (Eleocharis dulcis (Burm. f.) Hensch) cultivated in Australia, using random amplified polymorphic DNAs (RAPDs). J. Hortic. Sci. Biotech. 1999; 74, 224-31.

[20] SY Yeung, WH Lan, CS Huang, CP Lin, CP Chan, MC Chang and JH Jeng. Scavenging property of three cresol isomers against $\mathrm{H}_{2} \mathrm{O}_{2}$, hypochlorite, superoxide and hydroxyl radicals. Food Chem. Toxicol. 2002; 40, 1403-13.

[21] PA Sopade and MJ Gidley. A rapid in-vitro digestibility assay based on glucometry for investigating kinetics of starch digestion. Starch-Stärke. 2009; 61, 245-55.

[22] K Mahasukhonthachat, PA Sopade and MJ Gidley. Kinetics of starch digestion in sorghum as affected by particle size. J. Food Eng. 2010; 96, 18-28.

[23] I Goñi, A Garcia-Alonso and F Saura-Calixto. A starch hydrolysis procedure to estimate glycemic index. Nutr. Res. 1997; 17, 427-37.

[24] RW Hartel. Crystallization in Foods. In: AS Myerson (ed). $2^{\text {nd }}$ ed. Handbook of Industrial Crystallization, Woburn, Butterworth-Heinemann, 2002, p. 287-304.

[25] S Solomon, R Banerji, AK Shrivastava, P Singh, I Singh, M Verma, CP Prajapati and A Sawnani. Post-harvest deterioration of sugarcane and chemical methods to minimize sucrose losses. Sugar Tech. 2006; 8, 74-8.

[26] S Feng, Z Luo, Y Zhang, Z Zhong and B Lu. Phytochemical contents and antioxidant capacities of different parts of two sugarcane (Saccharum officinarum L.) cultivars. Food Chem. 2014; 151, 4528.

[27] JM Duarte-Almeida, A Salatino, MI Genovese and FM Lajolo. Phenolic composition and antioxidant activity of culms and sugarcane (Saccharum officinarum L.) products. Food Chem. 2011; 125, 660-4.

[28] MA Harish Nayaka, UV Sathisha, MP Manohar, KB Chandrashekar and SM Dharmesh. Cytoprotective and antioxidant activity studies of jaggery sugar. Food Chem. 2009; 115, 113-8.

[29] E Apostolidis, L Li, C Lee and NP Seeram. In vitro evaluation of phenolic-enriched maple syrup extracts for inhibition of carbohydrate hydrolyzing enzymes relevant to type 2 diabetes 
http://wjst.wu.ac.th

management. J. Funct. Foods 2011; 3, 100-6.

[30] P Naknean, M Meenune and G Roudaut. Characterization of palm sap harvested in Songkhla province, Southern Thailand. Int. Food Res. J. 2010; 17, 977-86.

[31] LT Cesar, M de Freitas Cabral, GA Maia, RW de Figueiredo, MRA de Miranda, PHM de Sousa, IM Brasil and CL Gomes. Effects of clarification on physicochemical characteristics, antioxidant capacity and quality attributes of açaí (Euterpe oleracea Mart.) juice. J. Food Sci. Tech. 2012; 51, 3293-300.

[32] LN Vhangani and J Van Wyk. Antioxidant activity of Maillard reaction products (MRPs) derived from fructose-lysine and ribose-lysine model systems. Food Chem. 2013; 137, 92-8.

[33] WR Jaffé. Health effects of non-centrifugal sugar (NCS): A review. Sugar Tech. 2012; 14, 87-94.

[34] US Kadam, SB Ghosh, S De, P Suprasanna, TPA Devasagayam and VA Bapat. Antioxidant activity in sugarcane juice and its protective role against radiation induced DNA damage. Food Chem. 2008; 106, 1154-60.

[35] SM Sabir, SD Ahmad, A Hamid, MQ Khan, ML Athayde, DB Santos, AA Boligon and JBT Rocha. Antioxidant and hepatoprotective activity of ethanolic extract of leaves of Solidago microglossa containing polyphenolic compounds. Food Chem. 2012; 131, 741-7.

[36] G Cao, E Sofic and RL Prior. Antioxidant and prooxidant behavior of flavonoids: Structure-activity relationships. Free Radic. Biol. Med. 1997; 22, 749-60.

[37] R Edenharder and D Grünhage. Free radical scavenging abilities of flavonoids as mechanism of protection against mutagenicity induced by tert-butyl hydroperoxide or cumene hydroperoxide in Salmonella typhimurium TA102. Mutat. Res. Toxicol. Environ. Mutagen. 2003; 540, 1-18.

[38] C Gallardo, L Jiménez and MT García-Conesa. Hydroxycinnamic acid composition and in vitro antioxidant activity of selected grain fractions. Food Chem. 2006; 99, 455-63.

[39] DJA Jenkins, CWC Kendall, LSA Augustin, S Franceschi, M Hamidi, A Marchie, AL Jenkins and M Axelsen. Glycemic index: Overview of implications in health and disease. Am. J. Clin. Nutr. 2002; 76, 266S-73S.

[40] TP Trinidad, AC Mallillin, RS Sagum and RR Encabo. Glycemic index of commonly consumed carbohydrate foods in the Philippines. J. Funct. Foods 2010; 2, 271-4.

[41] PK Vayalil. Date fruits (Phoenix dactylifera Linn): An emerging medicinal food. Crit. Rev. Food Sci. Nutr. 2012; 52, 249-71. 